\title{
POPULATION STRUCTURE OF Spodoptera frugiperda COLLECTED IN MAIZE FROM DIFFERENT BRAZILIAN GEOGRAPHIC REGIONS
}

\author{
ISABEL REGINA PRAZERES DE SOUZA ${ }^{1}$, SIMONE MARTINS MENDES ${ }^{1}$, \\ HENRIQUE ALBANO RAFAEL ${ }^{2}$, BEATRIZ DE ALMEIDA BARROS ${ }^{1}$, \\ MARCOS DE OLIVEIRA PINTO ${ }^{1}$, NEWTON PORTILHO CARNEIRO ${ }^{1}$, \\ UBIRACI GOMES DE PAULA LANA ${ }^{1}$, ELENA CHARLOTTE LANDAU ${ }^{1}$, \\ CARLOS ALEXANDRE GOMES RIBEIRO ${ }^{3}$ and MARIA MARTA PASTINA ${ }^{1}$
}

Revista Brasileira de Milho e Sorgo, v.14, n.3, p. 300-315, 2015

\begin{abstract}
${ }^{1}$ Embrapa Milho e Sorgo, Sete Lagoas, Minas Gerais, Brazil - isabel.prazeres@embrapa.br (Corresponding author), simone.mendes@embrapa.br,beatriz.barros@embrapa.br,marcos.deoliveira@embrapa.br, newton.carneiro@embrapa.br, ubiraci.lana@embrapa.br, charlotte.landau@embrapa.br,marta.pastina@embrapa.br ${ }^{2}$ Biology department, UNIFEMM, Sete Lagoas, Minas Gerais, Brazil-henriquealbanorafael@hotmail.com ${ }^{3}$ Federal University of Viçosa (UFV), Viçosa, Minas Gerais,Brazil-carlosbiotec@yahoo.com.br
\end{abstract}

\begin{abstract}
Spodoptera frugiperda is the most economically important maize pest in Brazil. There is little information about the genetic structure, using SSR markers, of S. frugiperda populations collected from maize crops. In this study, 21 SSR markers were used to evaluate the genetic diversity and population structure of $S$. frugiperda collected from distinct Brazilian geographical regions. Two hundred and twenty-seven alleles were recorded with an average of 10.76 per marker, and Polymorphic Information Content (PIC) values ranging from 0.242 to 0.933 , with an average of 0.621 , indicating a high discriminating power. The overall $\mathrm{F}_{\mathrm{ST}}, 0.061$, indicated a moderate genetic differentiation among the S. frugiperda populations collected from maize, and the AMOVA showed that $87.36 \%$ of the genetic variation is within populations. The Mantel test showed significant correlation between genetic and geographic distances. The genetic data demonstrated that all individuals from the six sampling sites were structured as two sub-populations, being one of them composed only by the CL population, collected in the Rio Grande do Sul state. The knowledge about genetic diversity and population structure of $S$. frugiperda is important for the development of strategies for the insect pest management and monitoring systems, especially for the differentiated CL population.
\end{abstract}

Key words: Zea mays L., SSR markers, fall armyworm, genetic structure.

\section{ESTRUTURA POPULACIONAL DE Spodoptera Frugiperda COLETADA EM MILHO DE DIFERENTES REGIÕES GEOGRÁFICAS BRASILEIRAS}

RESUMO - Spodoptera frugiperda é a praga do milho de maior importância econômica no Brasil. Existe pouca informação disponível sobre a estrutura genética, utilizando marcadores SSR, de populações de S. Frugiperda coletadas em cultivos de milho.Neste estudo, 21 marcadores SSR foram utilizados para avaliar a diversidade e a estrutura genética de S. frugiperda coletadas em regiões brasileiras geograficamente distintas. Um total de 227 alelos foram obtidos, com uma média de 10,76 alelos por marcador, e os valores do Conteúdo de Informação Polimórfica (PIC) variaram de 0,242 a 0,933, com uma média de 0,621 , indicando alto poder de discriminação. O FST geral, 0,061, indicou moderada diferenciação genética entre as populações de $S$. frugiperda coletadas em milho e a Amova mostrou que 87,36\% da variação está dentro de populações. O teste de Mantel mostrou correlação significativa entre distâncias genéticas e distâncias geográficas. Os dados genéticos demonstraram que todos os indivíduos dos seis locais de amostragem foram estruturados em duas sub-populações, sendo uma delas composta apenas pela população CL, coletada no estado do Rio Grande do Sul. O conhecimento sobre a diversidade genética e a estrutura populacional de $S$. frugiperda é importante para o desenvolvimento de estratégias para os sistemas de manejo e monitoramento de insetos-praga, especialmente para a diferenciada população CL.

Palavras-chave: Zea mays L., marcadores SSR, lagarta-do-cartucho, estrutura genética. 
The fall armyworm, Spodoptera frugiperda, described in 1797 by J.E. Smith, is an endemic insect to the Western Hemisphere, with a wide geographical distribution from the United States to Argentina (Martinelli et al., 2006; Vélez-Arango et al., 2008; Pogue, 2002). It is a polyphagous pest, becoming one of the most harmful species for annual crops in tropical regions of the Americas. Particularly in Brazil, $S$. frugiperda occurs throughout the year in different crop species, such as maize (Zea mays L.), sorghum (Sorghum bicolor (L.) Moench), cotton (Gossypium herbaceum L.), pasture (Panicum maximum Jacq. Hp. Tanzania); sugarcane (Saccharum officinarum L.), soybean (Glycine max (L.) Merrill) and rice (Oryza sativa L.) (Busato et al., 2004a; Boregas et al., 2013 and Juarez et al 2012).

In the larval stage, the fall armyworm feeds mainly from the whorl of young plants and may cause losses over $30 \%$ in the Brazilian maize production (Cruz, 1995). However, data about reductions in crop yield are still scarce, as these depend on factors such as environment, cultivar, agricultural practices, and especially the developmental stage and nutritional status of plants. Furthermore, the voracity of the fall armyworm strain is a factor that can influence the losses in production (Cruz, 1995; Busato et al., 2008), mainly considering the breakdown of resistance to Bt proteins in the country (Farias et al., 2014), when the maize crops were $80 \%$ Bt transgenic plants (Celeres, 2013).

Nagoshi et al. (2008) mentioned that a more detailed understanding of fall armyworm population movements will facilitate efforts to find more accurate ways to predict the timing and severity of infestations. Some studies have shown the existence of two strains that inhabit the same area in the United States, occurring at the same time and tending to use different hosts (Pashley, 1986). The "rice strain" was found feeding on rice, Brachiaria and other grasses, while the "maize strain" was found feeding on maize and cotton (Pashley, 1993). These strains were also identified in other countries, including Brazil (Busato et al., 2008). These authors reported the importance of $S$. frugiperda strains to the economical entomology, as they may respond differentially to strategies of control. Salinas-Hernandez et al. (2011) found no evidence for strains of $S$. frugiperda due to the host under Colombia conditions. However, Juarez et al. (2012) working with individuals of this species collected in Brazil, Argentina and Paraguay, detected the existence of mitochondrial "rice" and "maize" host haplotypes and identified that the distribution of the rice haplotype was apparently more widespread, being found in other hosts such as alfalfa.

The identification and characterization of the genetic variation among insect populations is an important issue to the development of strategies for pest management. However there is a lack of knowledge about the genetic variation of $S$. frugiperda collected in maize from distant regions of Brazil using SSR (Simple Sequence Repeats) markers, which are highly polymorphic and abundant throughout all eukaryotic genomes (Goldstein and Scholötterer, 1999). SSR has been the most widely applied class of molecular markers used in genetic studies (Ellegren 2004), because of its codominance, multiallelism, high reproducibility and PCR-based reaction (Oliveira et al., 2006).

To have success using practices for the integrated pest management and control of $S$. frugiperda in maize, it is important to characterize populations and the dispersion pattern of this pest (Busato et al., 2004b). In this context, the objective of this study was to investigate the genetic diversity and population structure of fall armyworm from 
six different maize producing areas over a large geographic area of Brazil.

\section{Material and Methods}

\section{Insect collection}

The larvae were collected randomly in equidistant points inside the non-transgenic maize fields in six Brazilian regions (Figure 1) (collection permit emitted by Brazilian Institute of Environment - IBAMA/SISBIO \# 35100). One hundred individuals were collected from each region for later selection, aiming to maintain representation of the population. For transportation each individual was placed in plastic cups of the $50 \mathrm{ml}$, containing adapted diet for rearing S. frugiperda (Kasten Jr et al., 1978).

In the lab, the larvae was stored in ethanol $99,5 \%(\mathrm{v} / \mathrm{v})$ and kept at $4^{\circ} \mathrm{C}$. The ethanol was changed daily for three days to avoid DNA degradation due to dilution by water released from the larvae (Souza et al., 2013). After that, the fall armyworm larvae were stored in a $-20^{\circ} \mathrm{C}$ freezer up to the DNA extraction. The identification of the collected larvae was performed

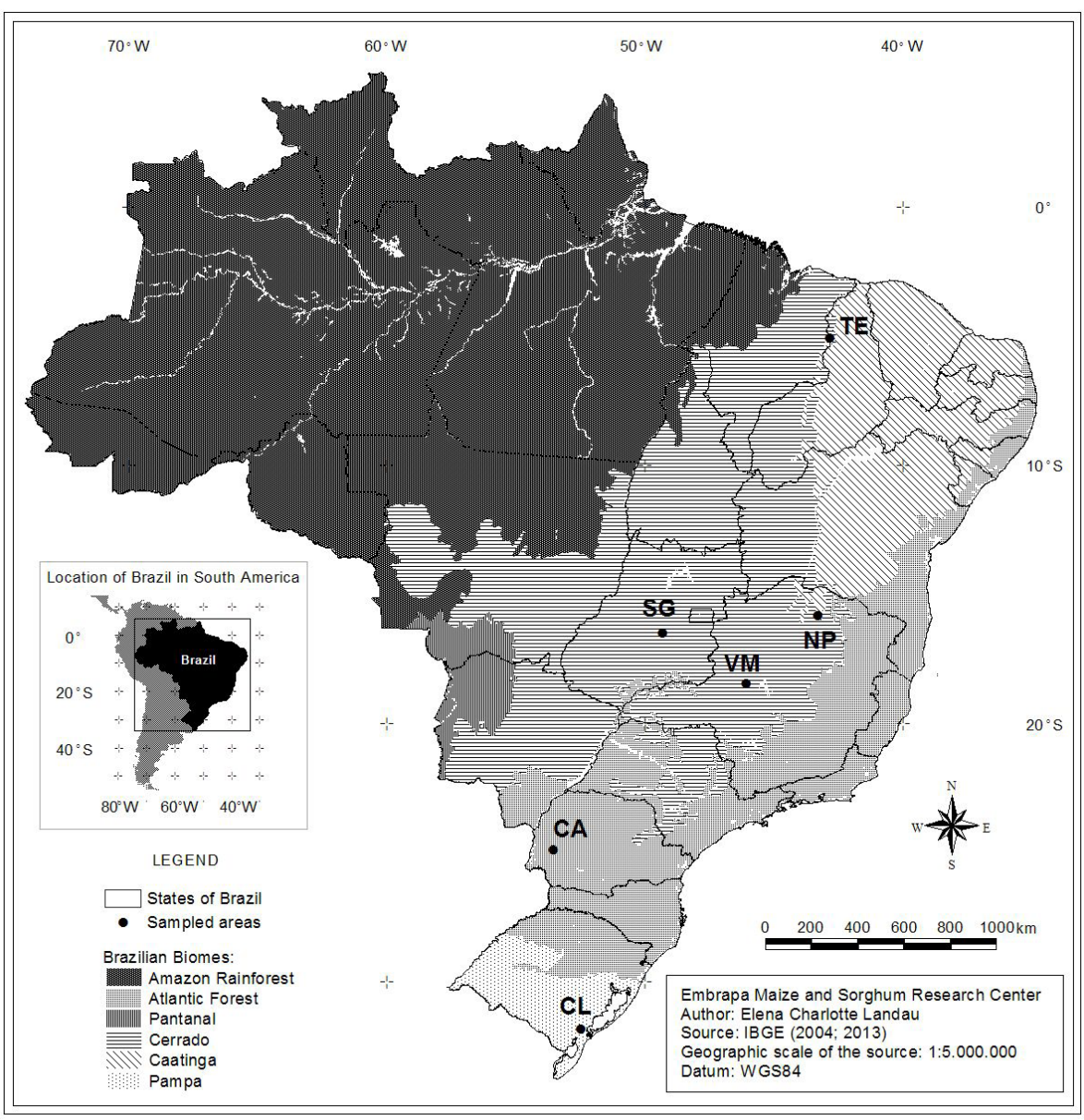

FIGURE 1. Sampled areas of Spodoptera frugiperda in Brazil. TE: Teresina, PI; NP: Nova Porteirinha, MG; VM: Varjão de Minas, MG; SG: Santo Antônio de Goiás, GO; CA: Cascavel, PR; CL: Capão do Leão, RS. The Brazilian biomes are identified in the legend. 
according to Luginbill (1928) description.

\section{DNA extraction and SSR markers amplification}

Larvae in the fourth instar or above were selected and the genomic DNA extracted according to Rogers and Bendich (1988) with some modifications (Souza et al., 2013). Twelve larvae from each population had the heads isolated and homogenized in extraction buffer [Tris- $\mathrm{HCl}$ $200 \mathrm{mM}(\mathrm{pH} \mathrm{8,0),} \mathrm{EDTA} 70 \mathrm{mM}, \mathrm{NaCl} 2 \mathrm{M}$, BSA $2 \%(\mathrm{w} / \mathrm{v})$, PVP $2 \%(\mathrm{w} / \mathrm{v})$ and $\beta$-mercaptoetanol $5 \%(\mathrm{v} / \mathrm{v})]$. CTAB $(2 \% \mathrm{w} / \mathrm{v})$ and Proteinase K (170 $\mu \mathrm{g} / \mathrm{mL}$ ) were added and the homogenate was incubated at $65^{\circ} \mathrm{C}$ for $1 \mathrm{~h}$. DNA was isolated with chloroform:octanol (24:1) and precipitated adding 1 volume of $-20{ }^{\circ} \mathrm{C}$ isopropanol $99,98 \%$ and 0,45 volume of ammonium acetate $5 \mathrm{M}$. After incubation for $2 \mathrm{~h}$ at $-20^{\circ} \mathrm{C}$, the samples were centrifuged and DNA pellet was rinsed with $70 \%(\mathrm{v} / \mathrm{v})$ ethanol, air dried and, resuspended in TE buffer containing RNase A $(40 \mu \mathrm{g} / \mathrm{mL})$. The DNA was quantified using the Nanodrop 1000 (Thermo Scientific, Inc) and diluted to a concentration of $10 \mathrm{ng} / \mu \mathrm{L}$.

\section{M13-tailed SSR method}

A total of 27 SSR sequence-specific primers developed for fall armyworm (Arias et al., 2011) were synthetized with M13 tail sequence (5', CAGTTTTCCCAGTCACGAC 3') at the 5'end. PCR analyses were carried out with three primers: a sequence-specific forward primer with M13 (19 nt) tail at its 5' end, a sequence-specific reverse primer, and the universal fluorescent-labeled M13 primer with 6-carboxy-fluorescein (FAM). The M13labelled primer and the reverse primer were in excess over the forward primer, which is limited. This allows the forward M13-tailed primer and reverse primer to initiate the reaction and, when the limited primer is depleted, the labelled primer takes the place of the limited forward primer in the remaining PCR cycles (Barkley et al., 2007; Schuelke, 2000).

PCR reactions consisted of 30 ng DNA, 0.5X Colorless GoTaq ${ }^{\circledR}$ Flexi Buffer (Promega Madison, WI), $1.5 \mathrm{mM} \mathrm{MgCl} 2,0.2 \mathrm{mM}$ dNTPs, 0.5 U GoTaq ${ }^{\circledR}$ Flexi DNA Polymerase (Promega Madison, WI), 5 pmol of each reverse and FAM-M13 primers and 2 pmol of the forward primer. Conditions of the PCR amplification were: $94^{\circ} \mathrm{C}(5 \mathrm{~min})$, then 30 cycles at $94^{\circ} \mathrm{C}(30 \mathrm{~s}) / 56^{\circ} \mathrm{C}(45 \mathrm{~s}) / 72^{\circ} \mathrm{C}(45 \mathrm{~s})$, followed by 8 cycles at $94^{\circ} \mathrm{C}(30 \mathrm{~s}) / 53^{\circ} \mathrm{C}(45 \mathrm{~s}) / 72^{\circ} \mathrm{C}(45 \mathrm{~s})$, and a final extension at $72^{\circ} \mathrm{C}$ ( $10 \mathrm{~min}$ ) (Schuelke, 2000). Subsequently, $2 \mu \mathrm{l}$ of the PCR product was added to $7.5 \mu \mathrm{l}$ Hi-Di Formamide and $0.5 \mu \mathrm{ROX}$ standard (ABI, Foster City, CA) and ran on the ABI 3100 Genetic Analyzer (ABI, Foster City, CA). For the capillary electrophoresis performed on MegaBace (Amersham Biosciences) were used $2 \mu$ of the PCR products, $0.3 \mu \mathrm{L}$ of standard size GeneTAB500 (GeneID) and $9.7 \mu \mathrm{l}$ tween $20(0.1 \% \mathrm{v} / \mathrm{v})$. Data were evaluated using the Fragment Profile 1.2 Software (Amersham Biosciences) and GeneMapper 3.5 Software (ABI, Foster City, CA).

\section{Descriptive statistics}

Monomorphic primers and the ones exhibiting problems in the amplification were removed from data analysis. For each SSR marker, major allele frequency, allele number, variability, gene diversity, heterozygosity and PIC (Polymorphism Information Content) values were calculated using the PowerMarker software (Liu and Muse, 2005). PIC is 
defined as the measure of the discrimination power and informativeness for an SSR marker (Botstein et al., 1980).

\section{Clustering and population structure analyses}

Clustering analysis was performed through the Ward's method (Ward 1963), based on the Rogers' distance (Rogers, 1972), using the package ade4 (Dray et al. 2007) available in the $\mathrm{R}$ software (R Core Team, 2013). Population structure analysis was carried out through the software STRUCTURE (Pritchard et al., 2000), considering a burn-in period of 250,000 and 500,000 iterations with five replicates, assuming admixture model, noninformative priors and correlated allele frequencies, with a number of groups $(\mathrm{k})$ ranging from 1 to 10. The putative number of subpopulations was determined based on the $\Delta K$ statistics, which corresponds to a measure of the second-order rate of change in the likelihood between successive $K$ values (Evanno et al., 2005).

\section{Mantel test for matrices correlation}

The correlation between the genetic distance (Rogers' distance) and the geographic distance matrices was verified through the Mantel test (Mantel, 1967) implemented in the software Genes (Cruz, 2013), considering 10,000 simulations.

\section{F-statistics}

The Wright's F-statistics ( $\mathrm{F}_{\text {IS, }} \mathrm{F}_{\mathrm{ST} \text { and }} \mathrm{F}_{\mathrm{IT}}$ Wright, 1951), as well as the expected and observed heterozygosity per population, were estimated using the package hierfstat (Goudet, 2005) available in the R software (R Core Team, 2013). The 95\% confidence intervals for the $\mathrm{F}_{\text {IS }}$ coefficient were calculated based on 1,000 bootstrap replications. The observed and expected heterozygosity were calculated based on the average of all markers in each population. The analysis of molecular variance (AMOVA) was performed through the package pegas for $\mathrm{R}$ (Paradis, 2010). Gene flow $\left(N_{\mathrm{m}}\right)$ was calculated as $N_{m}=\left(1-F_{S T}\right) / 4 F_{S T}$ (Wright, 1951).

\section{Results}

\section{Polymorphism and allele frequency analysis of microsatellite loci}

Of the 27 microsatellite (SSR) markers tested, four of them were monomorphic (Stv_Spf688, Stv_Spf1068, Stv_Spf1890 and Stv_Spf1856) and two (Stv_Spf1409 and Stv_Spf1552) did not have satisfactory PCR amplicons. In total, the 21 polymorphic markers (Table 1) resulted in the identification of 227 alleles for the 72 individuals (6 populations). Considering all the SSR loci, allele size ranged from 103 to $242 \mathrm{bp}$, and allele frequency varied from 0.04 to 1.00 , depending on the population (Figure 2). Also, for the majority of loci, some alleles in common were observed among populations. The number of alleles scored per locus ranged from 4 to 27 for the markers Stv_Spf538 and Stv_Spf1592, respectively, with an average of 10.76 (Table 2), revealing a high level of genetic diversity of fall armyworm in Brazil. The diversity of alleles observed for the polymorphic loci demonstrates a high intrapopulational and low interpopulational variability. PIC values ranged from 0.242 to 0.933 for Stv_Spf148 and Stv_Spf1592, respectively, with 


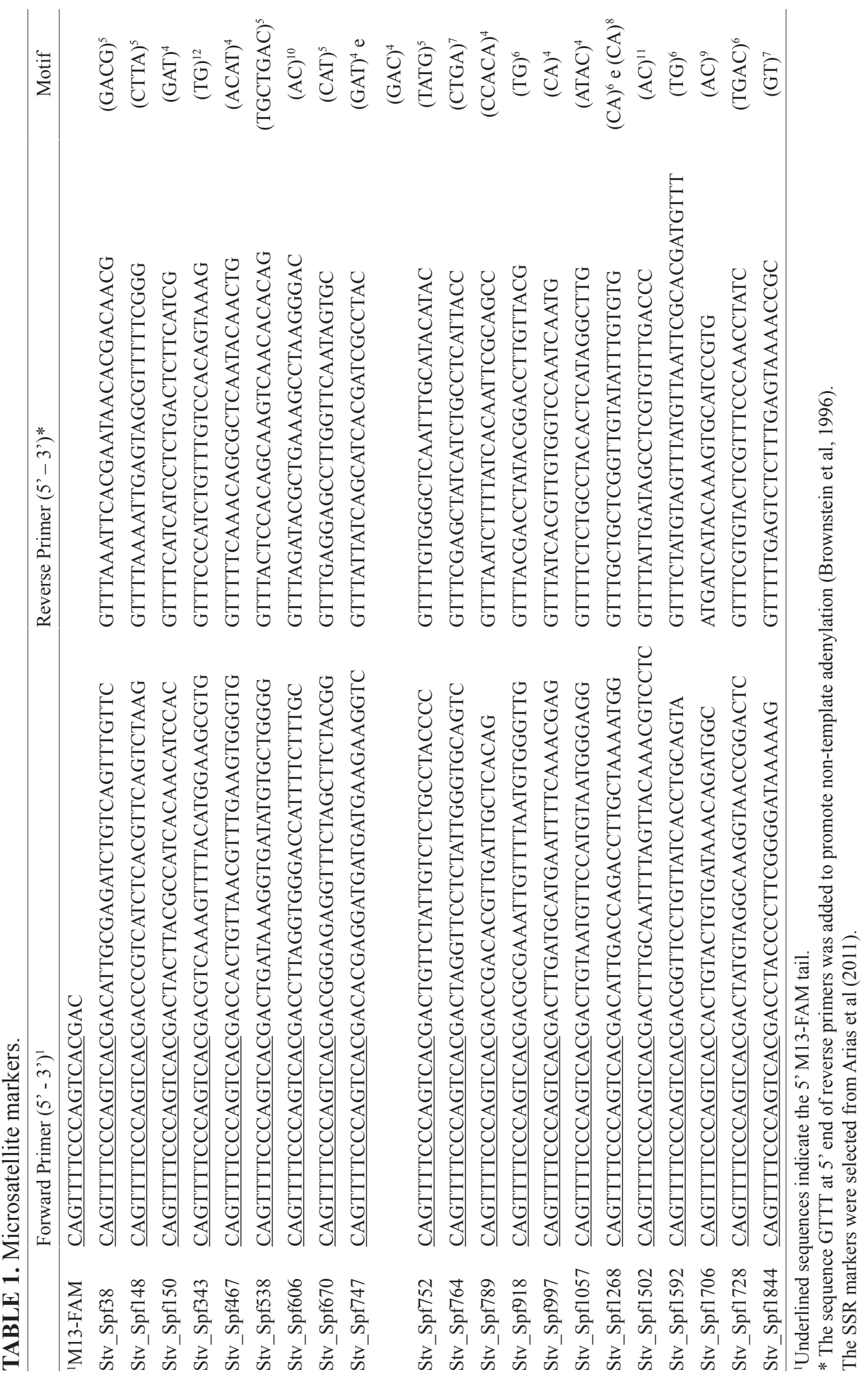



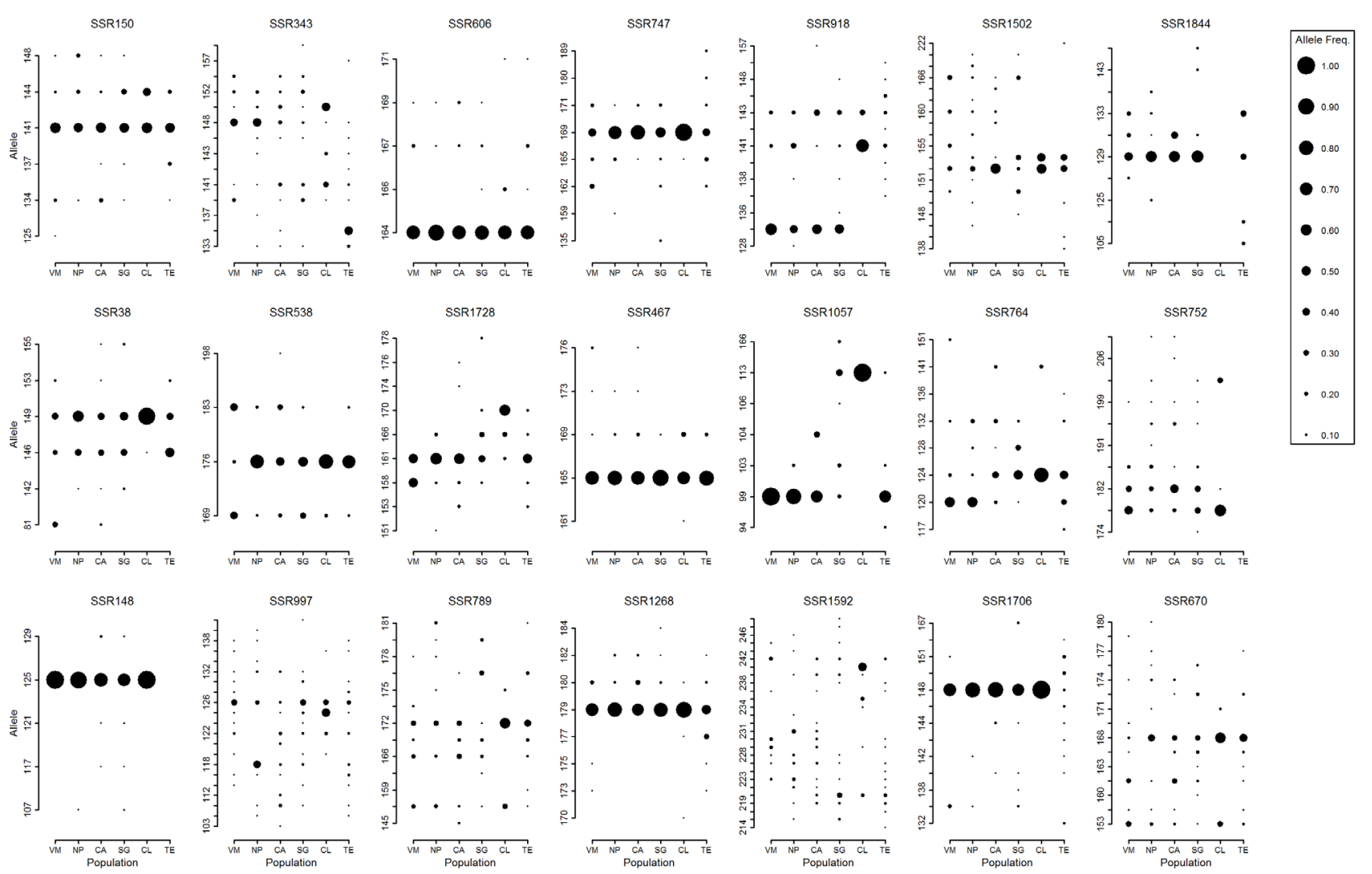

FIGURE 2. Frequency and size (bp) of alleles in the 21 microsatellite loci for each one of the six Spopodptera frugiperda populations. VM: Varjão de Minas; NP: Nova Porteirinha; CA: Cascavel; SG: Santo Antônio de Goiás; CL: Capão do Leão and TE: Teresina.

an average of 0.621 , and only four of them presented values below 0.5 . The high PIC values indicate the potential of these microsatellite markers in fall armyworm genetic diversity analysis.

\section{Genetic diversity and population structure}

The average values of mean observed heterozygosity $\left(H_{O}\right)$ and mean expected heterozygosity $\left(H_{E}\right)$ were 0,394 (ranging from 0,091 to 0,794 ) and 0,648 (ranging from 0,249 to 0,933 ), respectively (Table 2). For all markers, except for the Stv_Spf38 locus, the observed heterozygosity $\left(\mathrm{H}_{\mathrm{O}}\right)$ values were lower than the expected heterozygosity
$\left(\mathrm{H}_{\mathrm{E}}\right)$ values for all populations, indicating a deficit of heterozygotes relative to the expectations of Hardy-Weinberg equilibrium (HWE), suggesting the presence of inbreeding. The highest mean observed heterozygosity $\left(H_{O}\right)$ value $(0.461)$ was detected in the TE population whereas the lowest value (0.319) was recorded in the CL population (Table 3 ).

The local inbreeding coefficient $\left(\mathrm{F}_{\text {IS }}\right)$ was positive and ranged from 0.168 to 0.414 , for CL and CA populations, respectively, with an overall mean of 0.365 , and overall inbreeding coefficient $\left(\mathrm{F}_{\mathrm{IT}}\right)$ of 0.404 , indicating heterozygotes deficiency.

Comparing the six geographic populations, the overall fixation index $\left(\mathrm{F}_{\mathrm{ST}}\right)$ of 0.06 indicated 
TABLE 2. Number of alleles (A), observed heterozygosity $\left(\mathrm{H}_{\mathrm{O}}\right)$, expected heterozigosity $\left(\mathrm{H}_{\mathrm{E}}\right)$, and polymorphic information content (PIC) per marker

\begin{tabular}{lcccc}
\hline \multicolumn{1}{c}{ Marker } & $A$ & $H_{O}$ & $H_{E}$ & PIC \\
\hline Stv_Spf38 & 6 & 0.625 & 0.617 & 0.559 \\
Stv_Spf148 & 5 & 0.182 & 0.249 & 0.242 \\
Stv_Spf150 & 6 & 0.551 & 0.628 & 0.584 \\
Stv_Spf343 & 14 & 0.682 & 0.877 & 0.865 \\
Stv_Spf467 & 5 & 0.310 & 0.344 & 0.315 \\
Stv_Spf538 & 4 & 0.254 & 0.581 & 0.520 \\
Stv_Spf606 & 5 & 0.371 & 0.377 & 0.357 \\
Stv_Spf670 & 15 & 0.514 & 0.817 & 0.799 \\
Stv_Spf747 & 8 & 0.094 & 0.556 & 0.528 \\
Stv_Spf752 & 10 & 0.650 & 0.754 & 0.720 \\
Stv_Spf764 & 8 & 0.259 & 0.736 & 0.698 \\
Stv_Spf789 & 13 & 0.569 & 0.814 & 0.795 \\
Stv_Spf918 & 13 & 0.736 & 0.748 & 0.707 \\
Stv_Spf997 & 21 & 0.794 & 0.881 & 0.871 \\
Stv_Spf1057 & 7 & 0.061 & 0.543 & 0.514 \\
Stv_Spf1268 & 8 & 0.313 & 0.453 & 0.428 \\
Stv_Spf1502 & 19 & 0.276 & 0.801 & 0.788 \\
Stv_Spf1592 & 27 & 0.623 & 0.937 & 0.933 \\
Stv_Spf1706 & 13 & 0.147 & 0.511 & 0.501 \\
Stv_Spf1728 & 9 & 0.182 & 0.736 & 0.703 \\
Stv_Spf 1844 & 10 & 0.091 & 0.654 & 0.624 \\
\hline \multicolumn{1}{c}{ Mean } & 0.76 & 0.648 & 0.621 \\
\hline
\end{tabular}

TABLE 3. Mean observed heterozygosity $\left(H_{O}\right)$, mean expected heterozigosity $\left(H_{E}\right)$ and inbreeding coefficient $\left(F_{I S}\right)$, for each population and overall $F_{S T}$ and $F_{I T}$. CL: Capão do Leão; TE: Teresina; SG: Santo Antônio de Goiás; VM: Varjão de Minas; NP: Nova Porteirinha; and CA: Cascavel.

\begin{tabular}{cccccc}
\hline Population & mean $H_{O}$ & mean $H_{E}$ & $F_{I S}$ & $F_{S T}$ & $F_{I T}$ \\
\hline VM & 0.376 & 0.643 & 0.397 & & \\
NP & 0.388 & 0.595 & 0.361 & & \\
CA & 0.393 & 0.663 & 0.414 & & \\
SG & 0.438 & 0.689 & 0.339 & & \\
CL & 0.319 & 0.415 & 0.168 & & \\
TE & 0.461 & 0.731 & 0.356 & 0.404 \\
\hline Overall & 0.393 & 0.619 & 0.365 & 0.061 & \\
\hline
\end{tabular}


a moderate degree of differentiation among populations. An $\mathrm{F}_{\mathrm{ST}}$ index, ranging from 0 to 1 , is an estimate of gene differentiation among populations, which represents a genetic variation among fall armyworm populations (Nei, 1973). When $\mathrm{F}_{\mathrm{ST}}$ is equal to zero there is no genetic variation among populations. The estimated gene flow $\left(N_{\mathrm{m}}\right)$ over all populations, calculated based on the $\mathrm{F}_{\mathrm{ST}}$ value, was 3.484 , indicating the occurrence of migration among the sampled populations. $N_{\mathrm{m}}$ values higher than 1 generally indicate the presence of a significant gene flow among populations (McDermott and McDonald, 1993).

Through the clustering and population structure

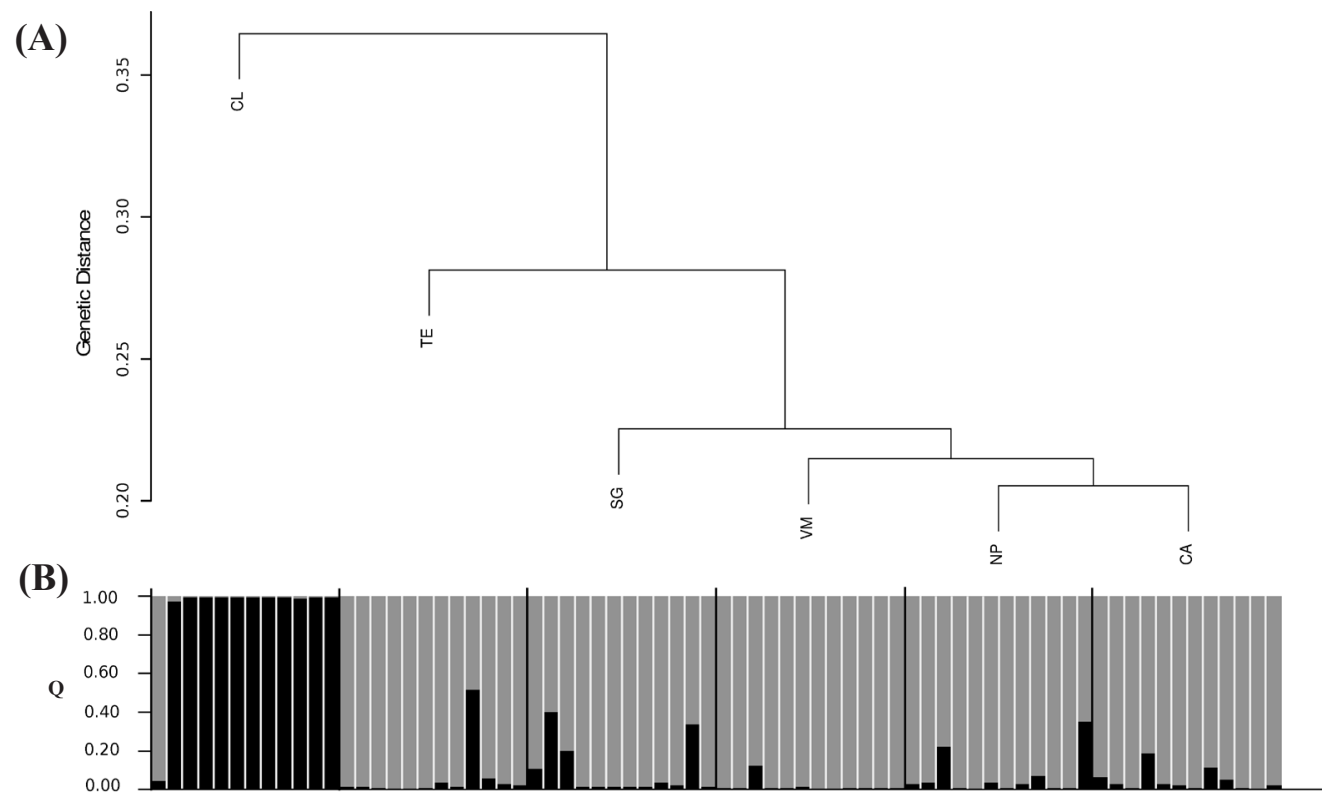

FIGURE 3. (A) Clustering analysis showing the genetic relationships among fall armyworm populations sampled from six areas in Brazil. (B) Population structure obtained through the software STRUCTURE, in which the putative number of subpopulations $(\mathrm{k}=2)$ was estimated based on the DK statistics (Evanno et al., 2005). Q corresponds to the posterior probability to assign an individual to a given subpopulation. Each one of the 72 individuals is represented by a vertical bar. Vertical black lines are separating the six sampled populations, in the following order: Capão do Leão (CL), Teresina (TE), Santo Antônio de Goiás (SG), Varjão de Minas (VM), Nova Porteirinha (NP) and Cascavel (CA). The colors (black and grey) inside the bars represent the probability of an individual to belong to one of the two subpopulations.

Revista Brasileira de Milho e Sorgo, v.14, n.3, p. 300-315, 2015

Versão impressa ISSN 1676-689X / Versão on line ISSN 1980-6477 - http://www.abms.org.br 
each individual belong to the group, suggested the existence of a certain degree of genetic relationship among CA, NP, VM, SG and TE populations. In both analyses, clustering and population structure, the six populations were genetically structured in two subpopulations.

\section{Analysis of molecular variance (AMOVA)}

The AMOVA (Table 4) showed that the difference among populations was significant $(\mathrm{P}<0.001)$, with the majority of the genetic variation residing within populations $(87.36 \%)$ than among populations (12.65\%), showing a modest differentiation among populations. The overall $\mathrm{F}_{\mathrm{ST}}$ value agrees with the results of the AMOVA, indicating a moderate genetic variability among populations.

\section{Correlation between genetic distance and geographic distance}

The correlation between the geographic and genetic distance matrices was significant at $5 \%$ of probability, accessed by the Mantel test, revealing a significant effect of the geographic isolation in the genetic variability observed among populations of S. frugiperda. The estimated genetic distance between the six populations presented slightly higher values for the pairs containing CL or TE (Table 5). These two populations, which were located at geographically distant areas in Brazil, South and Northeast, respectively, revealed a trend to increase the genetic differentiation as consequence of the increase in the distance of isolation. However, only for

TABLE 4. AMOVA performed for the six Brazilian populations of Spodoptera frugiperda.

\begin{tabular}{cccccc}
\hline $\begin{array}{c}\text { Source } \\
\text { of Variation }\end{array}$ & DF & Square Sum & $\begin{array}{c}\text { Variance } \\
\text { Components }\end{array}$ & $\begin{array}{c}\text { Percentage } \\
\text { of Variation }\end{array}$ & P-value \\
\hline Among populations & 5 & 2.044 & 0.02162 & 12.65 & $<0.001$ \\
Within populations & 66 & 9.856 & 0.14934 & 87.36 & \\
Total & 71 & 11.900 & 0.17096 & 100 & \\
\hline
\end{tabular}

TABLE 5. Rogers' (genetic) distance matrix (above the diagonal) between populations of Spodoptera frugiperda obtained through SSR markers, and geographic distance (in kilometers, km) (below the diagonal). VM: Varjão de Minas; NP: Nova Porteirinha; CA: Cascavel; SG: Santo Antônio de Goiás; CL: Capão do Leão and TE: Teresina.

\begin{tabular}{ccccccc}
\hline Population & VM & NP & CA & SG & CL & TE \\
VM & 0 & 0.218 & 0.212 & 0.245 & 0.405 & 0.313 \\
NP & 412 & 0 & 0.206 & 0.224 & 0.340 & 0.271 \\
CA & 1,057 & 1,468 & 0 & 0.208 & 0.360 & 0.277 \\
SG & 406 & 642 & 1,034 & 0 & 0.333 & 0.264 \\
CL & 1,619 & 2,004 & 780 & 1,730 & 0 & 0.386 \\
TE & 1,517 & 1,192 & 2,478 & 1,448 & 3,132 & 0 \\
\hline
\end{tabular}


the CL population the genetic differentiation seems to be affected by a putative geographic isolation. Our results suggested that for this population the geographical distance could be one of the limitations for the gene flow, as seen in the Figure 3B, with just one immigrant individual in population CL.

\section{Discussion}

The intensification of production systems in Brazil has allowed the cultivation of two and even three crops a year, favoring polyphagous pests like S. frugiperda to find suitable conditions for their maintenance in the field throughout the year. This sequential system allows $S$. frugiperda to have host plants over the year, reducing the adaptive value of migration (Farias et al., 2014). In face of an efficient management practices, it is necessary to know the genetic complexity and structure of the pest population, to delay the evolution of resistance to any control method (Tabashnik, 1991). Many studies have been conducted on genetic characterization of the fall armyworm, using strains from different crops, for example, rice, maize and cotton. Although these studies are commonly performed based on a limited sample size and a restricted number of molecular markers, small genetic variation among geographic regions has been found (Belay et al., 2012). It is important to know the genetic structure of fall armyworm from different maize producing areas before the use of large-scale efforts to control insect pests (Martinelli et al., 2007). Thus, the results of this study will contribute to improve the strategies for the management and control of pests in maize crops.

Here, in this study, 21 SSR markers selected from a first report of sequence-specific SSR for fall armyworm, developed by Arias et al (2011), were used for genotyping the individuals of six populations collected in distinct geographic Brazilian regions. Microsatellites were selected due to its highly polymorphic content, abundance across the genome and codominance (Weber 1990). These markers were polymorphic and highly informative (227 alleles), allowing to study the genetic variability of $S$. frugiperda collected in Brazil, being useful to detect genetic structure among the sampled populations. Also, these SSR will be important for further and different studies concentrated on $S$. frugiperda populations associated with different crops and over the crop seasons.

Two major distinctive groups were identified in the clustering analysis, one of them composed by TE, SG, VM, NP and CA populations, and another represented only by CL population, showing an effect of the region on the structure of the genetic variation, since the correlation of genetic distance to geographic distance was significant. The genetic distance observed in the dendrogram for the TE population in the major group, may result from the association of geographic distance, growing conditions and distinguished biome (Figure 1). The CL population was clustered according to its geographic distance of origin, indicating the presence of local barriers that limit the gene flow, and other factors besides the host plant have influenced the selection of genetic differences. In the state of Rio Grande do Sul, where the county of Capão do Leão (CL) is located, Busato et al. (2004a) identified a maize and rice strains of $S$. frugiperda. Later, Busato et al. (2008) verified restricted compatibility between the fall armyworm strains of rice and maize. Although mating occurred in both directions, they concluded that these two 
strains were in the initial process of speciation and represent strains associated with host. Besides that, they mentioned that was evident the nonpreference of these two strains for irrigated rice, barnyardgrass and sorghum in relation to maize (Busato et al., 2004b). The dispersion capability, the geographic barriers and other related process can also influence the population structure of a given species (Avise et al., 1987).

In our study, the majority of the genetic variability was observed within population and not among populations, confirming that the local populations are the principal reservoir of genetic variability. Similar studies with fall armyworm conducted by Belay et al (2012) using AFLP markers and samples collected in the United States, Puerto Rico, Panama and Argentina, Martinelli et al. (2006) and Busato et al. (2004b) using, respectively, AFLP and RAPD markers and samples from Brazil, also showed a higher degree of variation within populations than among populations.

The moderate degree of differentiation among populations, which resulted in the separation in two groups, supports the hypothesis of gene flow among populations. Martinelli et al. (2006) working with fall armyworm from maize and cotton collected in the state of Bahia, northeast of Brazil, suggested the existence of a considerable gene flow between these populations at the same geographical regions, however, we also found gene flow among populations located in distant regions of Brazil. Murúa et al. (2008) found no incompatibility among fall armyworm populations from the north of Argentina. However, indications of incompatibility were observed between the northern populations and a geographically distinct population from Buenos Aires.

Our study is the first one to apply the SSR markers developed by Arias et al (2011) in $S$. frugiperda populations from Brazil, and the results showed that the 21 selected SSRs allowed the detection and characterization of the genetic diversity among insect populations, showing effectiveness for the study of population structure. This information could be useful for monitoring migration among populations and for the improvement of pest management strategies. Pavinato et al. (2013) had also found degrees of genetic structure among three Brazilian populations, although it was a test validation for their six SSR markers, of which five dinucleotide and one compound, developed for the fall armyworm.

The intensive cultivation system and the intensive use of Bt maize in Brazil act in favor of an evolution toward a resistance to $\mathrm{Bt}$ maize in S. frugiperda (Farias et al., 2014). Moreover, the frequent genetic admixture of immigrant individuals into populations of $S$. frugiperda has the potential to influence the strategies for the management of an insect resistance (Roush and Daly, 1990). Also, the regular application and heavy selection pressure of insecticides has conducted to the development of resistant fall armyworm in many regions ( $\mathrm{Yu}$ 1991, Berta et al. 2000). In both situations, the knowledge about the genetic variability, structure and migration in armyworm populations will assist in the development of adequate management strategies, contributing to the preservation of these technologies. The identification of two populations can contribute to the IPM (Integrated Pest Management) strategies, with more specific control tools, especially for the Capão do Leão in the extreme south region.

In our study, the population structure of maize fall armyworm suggested the presence of two major groups showing significant correlation with 
their geographic sampling location in Brazil. These results reinforce the importance for differentiated management strategies in relation to these population groups and also, for further studies using SSR markers to evaluate the genetic variability and structure of the fall armyworm, from more maize regions over the crop seasons.

\section{Acknowledgments}

We would like to thank Brazilian Agricultural Research Corporation (Embrapa) for the partial financial support and Célio Ramos das Neves for helping with lab works.

\section{References}

ARIAS, R. S.; BLANCO, C. A.; PORTILLA, M.; SNODGRASS, G. L.; SCHEFFER, B. E. First microsatellites from Spodoptera frugiperda (Lepidoptera: Noctuidae) and their potential use for population genetics. Annals of the Entomological Society of America, College Park, v. 104, p. 576-587, 2011.

AVISE, J. C.; ARNOLD, J.; BALL, R. M.; BERMINGHAM, E.; LAMB, T.; NIEGEL, J. L.; REEBE, C. A.; SAUNDERS, N. C. Intraspecific phylogeography: the mitochondrial DNA bridge between population genetics and systematics. Annual Review of Ecology and Systematics, Palo Alto, v. 18, p. 489-522, 1987.

BARKLEY, N. A.; DEAN, R. E.; PITTMAN, R. N.; WANG, M.L.; HOLBROOK, C.C.;PEDERSON, G. A. Genetic diversity of cultivated and wildtype peanuts evaluated with M13-tailed SSR markers and sequencing. Genetics Research, v. 89, p. 93-106, 2007.

BELAY, D. K.; CLARK, P. L.; SKODA, S. R.;
ISENHOUR, D. J.; MOLINA-OCHOA，J.; GIANNI, C.; FOSTER, J. E. Spatial genetic variation among Spodoptera frugiperda (Lepidoptera: Noctuidae) sampled from the United States, Puerto Rico, Panama and Argentina. Annals of the Entomological Society of America, College Park, v. 105, p. 359-367, 2012. BERTA, D. C.; VIRLA, E. G.; COLOMO, M. V.; ANDVALVERDE, L. Efecto en el parasitoide Campoletis grioti de un insecticida usado para el control de Spodoptera frugiperda y aportes a la bionomía del parasitoide. Revista Manejo Integrado de Plagas, Turrialba, v. 57, p. 65-70, 2000.

BOREGAS, K. G. B.; MENDES, S. M.; WAQUIL, J. M.; FERNANDES, G. W. Fitness stage of Spodoptera frugiperda (JE Smith) (Lepidoptera: Noctuidae) on alternative hosts. Bragantia, Campinas, v. 72, p. 61-70, 2013.

BOTSTEIN, D.; WHITE, R. L.; SKOLNICK, M.; DAVIS, R. W. Construction of a genetic linkage map in man using restriction fragment length polymorphisms. American Journal of Human Genetics, Chicago, v. 32, p. 314-331, 1980.

BROWNSTEIN, M. J.; CARPTEN, J. D.; SMITH, J. R. Modulation of non-templated nucleotide addition by tag DNA polymerase: primer modifications that facilitate genotyping. Biotechniques, Natick, v. 20, p. 1004-1006, p. 1008-1010, 1996.

BUSATO, G. R.; GRUTZMACHER, A.; GARCIA, M.; GIOLO, F.; ZOTTI, M.; NORNBERG, S.; NEVES, M. Preferência e consumo de dois biótipos de Spodoptera frugiperda (J.E. SMITH, 1797) (Lepidoptera: Noctuidae) por folhas de milho e arroz irrigado. Revista Brasileira de Agrociência, Pelotas, v. 10, p. 317-322, 2004a.

BUSATO, G. R.; GARCIA, M. S.; LOECK, A. 
E.; ZART, M.; NUNES, A. M.; BERNARDI, O.; ANDERSSON, F. S. Análise da estrutura e diversidade molecular de populações de Spodoptera frugiperda (J.E. Smith, 1797) (Lepidoptera: Noctuidae) associadas ao milho e arroz no Rio Grande do Sul. Neotropical Entomology, Londrina, v. 33, p. 709-716, 2004b. BUSATO, G. R.; LOECK, A. E.; GARCIA, M. S.; BERNARDI, O.; ZART, M.; NUNES, A. M.; ZAZYCKI, C. F. Compatibilidade reprodutiva entre os biótipos "milho" e "arroz" de Spodoptera frugiperda (J.E. SMITH) (LEPIDOPTERA: NOCTUIDAE). Revista Brasileira de Agrociência, Pelotas, v. 14, p. 273-278, 2008.

CÉLERES. Relatório de biotecnologia. Uberlândia, 2013. Disponível em: <http://celeres.com. br/wordpress/wp-content/uploads/2013/ RelBiotecBrasil_1201vf.pdf $>$. Acesso em: 10 dez. 2014.

CRUZ, C.D. GENES a software package for analysis in experimental statistics and quantitative genetics. Acta Scientiarum. Agronomy, Maringá, v. 35, p. 271-276, 2013.

CRUZ, I. A lagarta-do-cartucho na cultura do milho. Sete Lagoas: Embrapa-CNPMS, 1995. 45 p. (Embrapa-CNPMS. Circular Técnica, 21).

DRAY, S.; DUFOUR, A. B. The ade4 package: implementing the duality diagram for ecologists. JournalofStatisticalSoftware,v.22,p.1-20,2007. ELLEGREN, H. Microsatellites: simple sequences with complex evolution. Nature Reviews Genetics, London, v. 5, p. 435-445, 2004.

EVANNO, G.; REGNAUT, S.; GOUDET, J. Detecting the number of clusters of individuals using the software STRUCTURE: a simulation study. Molecular Ecology, Oxford, v. 14, p. 2611-2620, 2005.
FARIAS, J. R.; ANDOW, D. A.; HORIKOSHI, R. J.; SORGATTO, R. J.; FRESIA, P.; SANTOS, A. C.; OMOTO, C. Field-evolved resistance to Cry1F maize by Spodoptera frugiperda (Lepidoptera: Noctuidae) in Brazil. Crop Protection, Guildford, v. 64, p. 150-158, 2014.

GOLDSTEIN, D.; SCHLÖTTERER, C.

Microsatellites: evolution and applications.

Oxford: Oxford University Press, 1999.

GOUDET, J. HIERFSTAT, a package for R to compute and test hierarchical F-statistics. Molecular Ecology Notes, Oxford, v. 5, p. 184-186, 2005.

JUAREZ, M. L.; MURUA, M. G.; GARCIA, M. G.; ONTIVERO, M.; VERA, M. T.; VILARDI, J. C.; GROOT, A. T.; CASTAGNARO, A. P.; WILLINK, E. Host association of Spodoptera frugiperda (Lepidoptera: Noctuidae) corn and rice strains in Argentina, Brazil, and Paraguay. Journal of Economic Entomology, Lanham, v. 105, p. 573-582, 2012.

KASTEN JÚNIOR, P.; PRECETTI, A. A. C. M.; PARRA, J. R. P. Dados biológicos comparativos de Spodoptera frugiperda (J.E. SMITH, 1797) em duas dietas artificiais e substrato natural. Revista de Agricultura, Piracicaba, v. 53 p. 69-78, 1978. LUGINBILL, P. The fall armyworm. Washington: USDA, 1928. 91 p. (USDA Technical Bulletin, $34)$.

LIU, K.; MUSE, S. V. Power Marker: integrated analysis environment for genetic marker data. Bioinformatics, v. 21, p. 2128-2129, 2005.

MANTEL, N. The detection of disease clustering and a generalized regression approach. Cancer Research, Baltimore, v. 27, p. 209-220, 1967.

MARTINELLI, S.; BARATA, R. M.; ZUCCHI, M. I.; SILVA FILHO, M. D. C.; OMOTO, C. Molecular variability of Spodoptera frugiperda 
(Lepidoptera: Noctuidae) populations associated to maize and cotton crops in Brazil. Journal of Economic Entomology, Lanham, v. 99, p. 519526, 2006.

MARTINELLI, S.; CLARK, P. L.; ZUCCHI, M. I.; SILVA FILHO, M. C.; FOSTER, J. E.; OMOTO, C. Genetic structure and molecular variability of Spodoptera frugiperda (Lepidoptera: Noctuidae) collected in maize and cotton fields in Brazil. Bulletin of Entomological Research, Farnham Royal, v. 97, p. 225-231, 2007.

McDERMOTT, J. M.; McDONALD, B. A. Gene flow in plant pathosystems. Annual Review of Phytophatology, v. 31, p. 353-373, 1993.

MURÚA, M. G.; VERA, M. T.; ABRAHAM, S.; JUARÉZ, M. L.; PRIETO, S.; HEAD, G. P.; WILLINK, E. Fitness and mating compatibility of Spodoptera frugiperda (Lepidoptera: Noctuidae) populations from different host plant species and regions in Argentina. Annals of the Entomological Society of America, College Park, v. 101, p. 639-649, 2008.

NAGOSHI, R. N.; MEAGHER, R. L. Review of fall armyworm (Lepidoptera: Noctuidae) genetic complexity and migration. Florida Entomologist, Gainesville, v. 91, p. 446-554, 2008.

NEI, M. Analysis of gene diversity in subdivided populations. Proceedings of the National of Academy of Sciences of the United States of America, Washington, v. 70, p. 3321-3323, 1973.

OLIVEIRA, E. J.; PADUA, J. G.; ZUCCHI, M. I.; VENCOVSKY, R.; VIEIRA, M. L. C. Origin, evolution and genome distribution of microsatellites. Genetics and Molecular Biology, Ribeirão Preto, v. 29, p. 294-307, 2006. PARADIS, E. PEGAS: An R package for population genetics with an integrated-modular approach.
Bioinformatics, v. 26, p. 419-420, 2010.

PASHLEY, D. P. Host-associated genetic differentiation in fall armyworm (Lepidoptera: Noctuidae): a sibling species complex. Annals of the Entomological Society of America, College Park, v. 79, p. 898-904, 1986.

PASHLEY, D. P. Causes of host-associated variation in insect herbivores: an example from fall armyworm. In: KIM, K. C.; MacPHERON, B. A. Evolution of insect pets: patterns of variation. New York: John Wiley \& Sons, 1993. p. 351-359. PAVINATO, V. A. C.; MARTINELLI, S.; LIMA, P. F.; ZUCCHI, M. I.; OMOTO, C. Microsatellite markers for genetic studies of the fall armyworm, Spodoptera frugiperda. Genetics and

Molecular Research, v. 12, p. 370-380, 2013. POGUE, G. M. A world revision of the genus Spodoptera Guenée (Lepidoptera: Noctuidae). Memoirs of the American Entomological Society, v. 43, p.1- 202, 2002.

PRITCHARD, J. K.; STEPHENS, M.; DONNELLY, P. J. Inference of population structure using multilocus genotype data. Genetics, Austin, v. 155, p. 945-959, 2000.

R CORE TEAM. R: A language and environment for statistical computing. Vienna: R Foundation for Statistical Computing, 2013. Disponível em: $<$ http://www.R-projetct.org $>$. Acesso em: $10 \mathrm{dez}$. 2014.

ROGERS, J. S. Measures of genetic similarity and genetic distances. Studies in Genetics, v. 7213, p. $145-153,1972$.

ROGERS, O. S.; BENDICH, A. J. Extraction of DNA from plant tissues. Dordrecht: Kluwer Academic Publishers, 1988. (Plant Molecular Biology Manual).

ROUSH, R. T.; DALY, J. C. The role of population 
genetics in resistance research and management. In: ROUSH, R. T.; TABASHNIK, B. E. (Ed.). Pesticide resistance in arthropods. New York: Chapman \& Hall, 1990. p. 97-152.

SALINAS-HERNANDEZ, H.; SALDAMANDOBENJUMEA, C. I. Haplotype identification within Spodoptera frugiperda (J.E. Smith) (Lepidoptera: Noctuidae) corn and rice strains from Colombia. Neotropical Entomology, Londrina, v. 40, p. 421-430, 2011.

SCHUELKE, M. An economic method for the fluorescent labeling of PCR fragments. Nature Biotechnology,NewYork, v. 18,p. 233-234,2000. SOUZA, I. R. P.; BARROS, B. A.; LANA, U. G. P.; RAFAEL, H. A.; MENDES, S. M.; LEITE, N. A. Preservação de amostras e extração de DNA de Spodoptera frugiperda. Sete Lagoas: Embrapa Milho e Sorgo, 2013. 20 p. (Embrapa Milho e Sorgo. Boletim de Pesquisa e Desenvolvimento, 68).

TABASHNIK, B. E. Determining the mode of inheritance of pesticide resistance with blackcross experiments. Journal of Economic Entomology, Lanham, v. 84, p. 703-712, 1991. VÉLEZ-ARANGO, A. M.; ARANGO, R. E.; VILLANUEVA, D.; AGUILERA, E.; SALDAMANDO, C. I. Identificación de biotipos de Spodoptera frugiperda (Lepidoptera: Noctuidae) mediante marcadores mitocondriales y nucleares. Revista Colombiana de Entomologia, Bogotá, v. 34, p. 145-150, 2008. WARD, J. H. Hierarchical grouping to optimize an objective function. Journal of the American Statistical Association, New York, v. 58, p. 236-244, 1963.

WEBER, J. L. Informativeness of human (Dc-Da) N. (Dg-Dt) N polymorphisms. Genomics, San
Diego, v. 7, p. 524-530, 1990.

WRIGHT, S. The genetical structure of populations. Annals of Eugenics, London, v. 15, p. 323-354, 1951.

YU, S. J. Insecticide resistance in the fall armyworm, Spodoptera frugiperda (J. E. Smith).Pesticide Biochemistry and Physiology, San Diego, v. 39, p. 84-91, 1991. 